\title{
Gender and the Effectiveness of Leadership Training: Results from a Field Experiment
}

Forthcoming, Review of Public Personnel Administration

\author{
Seung-Ho An \\ School of Government and Public Policy \\ University of Arizona \\ seunghoan@,arizona.edu \\ and \\ Kenneth J. Meier \\ School of Public Affairs \\ American University, \\ School of Business \\ Cardiff University, \\ and \\ the Institute of Public Administration \\ Leiden University \\ kmeier@american.edu
}

Suggested citation: An, Seung-Ho and Kenneth J. Meier. 2020. "Gender and the Effectiveness of Leadership Training: Results from a Field Experiment." Review of Public Personnel Administration. Online First. https://doi.org/10.1177/0734371X20932989

An earlier version of this paper was presented at the annual conference of the European Group on Public Administration, Utrecht, the Netherlands, August 24-26, 2016. We would like to thank Lotte Bøgh Andersen and Suyeon Jo for comments on an earlier draft. Support for this research was provided by the Danish Council for Independent Research, project no. 1327-00015B. 


\begin{abstract}
This study examines gender differences in leadership behaviors and whether leadership training would have different effects on leadership behaviors by gender. Using data from several hundred managers of welfare and financial agencies in Denmark, we first investigate whether leadership behaviors differ between female and male leaders. After that, we conducted a year-long field experiment with managers to examine how female and male leaders respond to leadership training interventions. In general, female managers improve more from leadership training even though leadership scores for female leaders were higher before training.
\end{abstract}




\section{Introduction}

Leaders $^{1}$ are responsible for a multitude of functions in organizations and effective leadership skills, therefore, are necessary for them to successfully manage organizations. Leadership training is a way to improve leadership skills, serving as a venue for leaders to learn how to create the inducements-contributions balance between the organization and employees. Public organizations are not an exception when it comes to training skillful leaders. According to the U.S. Office of Personnel Management website, a total of sixty federal agencies provide two hundred and forty-four leadership programs for various grade levels of employees. ${ }^{2}$ Though organizations, regardless of sector and industry, spend a large amount of human and financial resources on training leaders (Seidle, Fernandez, and Perry 2016), few studies in public human resource management examine the effectiveness of leadership training.

For leadership training to be effective, one may need to consider different characteristics of leaders. One noticeable difference among leaders is gender. Diverse theories from gender role theory to leadership theory indeed suggest that women and men may exert different behaviors when they serve as organizational leaders (e.g., Eagly 2013; Eagly, Johannesen-Schmidt, and Van Engen, 2003; Eagly and Wood 2016). Women leaders tend to be more democratic and participatory while male leaders are more independent and assertive (see the discussion below). The generic management literature and the research in public management also point to clear gender differences in management styles. An extensive meta-analysis finds that women managers actually rate higher than men in terms of both transformational and transactional

\footnotetext{
${ }^{1}$ In this article, we use the terms of leaders and managers, interchangeably. Leaders (or managers) in our paper refer to individuals with supervisory roles (managing frontline employees).

${ }^{2}$ The information is retrieved from the Office of Personal Management website on February $3^{\text {rd, }}$ 2019; access at https://www.opm.gov/services-for-agencies/federal-leadership-development-programs/\#url=Search-the-Catalogue.
} 
leadership (Eagly, Johannesen-Schmidt, and Van Engen, 2003). Studies in public management similarly show both value differences between male and female managers and differences in behaviors (Dolan 2000; Hamidullah, Riccucci and Pandey 2015; Jacobson, Paulus, and Bowling 2010; Meier, O'Toole and Goerdel 2006). The potential differences in leadership styles between female and male leaders are important when it comes to leadership training; leadership training may have different effects on male and female leaders in improving their leadership skills simply because men and women might differ in perceptions of appropriate leadership and respond accordingly.

Using data from randomized field experiments on leadership training in Denmark, this study examines whether leadership training affects female and male leaders differently. The field experiments involved the random assignment of several hundred Danish public managers to different forms of leadership training (transformational, transactional, combined transformational and transactional, plus a control group). Before and after assessments of leadership by both leaders and their employees allow testing our hypotheses on gender and leadership training. This study also contributes to the literature examining the relationship in various public organizations (e.g. daycare centers, public schools, and tax offices) in a country with strong gender equality. ${ }^{3}$

This study focuses on transformational and transactional leadership styles for the following reasons. First, transformational leadership styles fit the theoretical literature arguing that women are more likely to adopt democratic and participatory leadership styles, thus predicting that transformational leadership training will have a stronger impact on women and that the more traditional transactional leadership style will be more influential for men. Second,

\footnotetext{
${ }^{3}$ Denmark has a strong gender equality compared to other OECD countries, especially regarding equal opportunities for education and political participation (Statistics Denmark 2020; World Economic Forum, 2020). More details will be introduced later in the context section.
} 
because women leaders generally score higher on leadership assessments, training might be subject to diminishing marginal returns; and the leadership training (both transformational and transactional) might be less effective for women managers.

In testing these hypotheses, this article proceeds as follows. First, we briefly discuss the concepts of transformational and transactional leadership and how they can be distinguished from one another. Second, we link leadership theories to organization-based gender theories, thereby explaining how leadership training may affect women and men. We also present our hypotheses in this section. Third, we introduce our experimental research design, methods, and context. Fourth, we explore how employees rate their leaders' leadership behaviors differently by gender of their leader and then present research findings with regard to leadership training effects for female and male leaders. Lastly, we provide suggestions for future research and conclude with some remarks and limitations of this study.

\section{Transformational and Transactional Leadership}

A common belief among much of the generic leadership literature is that leadership behaviors are universal; the skill sets for being an effective leader may not vary according to types of individuals or organizations. Stimulated by Terry (2003), however, who argued the importance of administrative (or bureaucratic) leadership particularly in public organizations, public administration scholars have made substantial efforts to better understand leadership styles in the public sector. This literature has generally adopted leadership theories from the business management literature and applied them to the public organizations (for more details see Van Wart, 2003, 2013). In the process a contingency theory of leadership has developed that suggests 
the appropriate style of leadership is conditional on both the characteristics of the leader and the characteristics of the situation.

While these theories on leadership can be used in comprehending leaders in the public sector, recent studies have highlighted the distinction between two effective types of generic leadership: transformational and transactional leadership. ${ }^{4}$ First, the idea of transactional leadership is predicated upon social and economic exchanges between leaders and employees (Vigoda-Gadot and Beeri, 2012); leaders provide their followers with verbal or material rewards in exchange for good performance, and punishment is available for the poor performance. The expected consequence of using transactional leadership is incentivizing employees to work harder to obtain rewards and/or to avoid punishment, so that individuals align their personal goals with organizational objectives (Barnard, 1938; Simon, 1976).

Transformational leadership, on the other hand, moves beyond the concept of social exchanges and focuses on another critical skill set necessary for an effective leader in an organization (Bass et al., 2003; Wright, Moynihan, and Pandey 2012). Because organizational visions that challenge individual employees can enhance productivity, leaders should play a role in inspiring, motivating, and stimulating their followers to accomplish these goals (Ashikali and Groeneveld, 2015; Burns, 1978; Bass, 1985; Caillier, 2016). By doing so, employees exert greater effort and may be able to achieve challenging goals that were once regarded as being beyond their capacity. Although different in orientation, both transformational and transactional leadership are associated with positive organizational and human resources outcomes, such as greater organizational performance, and higher worker productivity and job satisfaction (for

\footnotetext{
${ }^{4}$ We focus on transformation and transactional leadership rather than other forms of leadership because both of these forms of leadership are consistently related to organizational performance. Our field experiment follows the medical maxim of "do no harm," that is, it would be unethical to provide leadership training that we know was not effective simply to generate research results.
} 
more details see An, Meier, Ladenburg, and Westergård-Nielsen 2019; Bass 1985; Bass and Riggio, 2006).

Many scholars have argued both transactional and transformational leadership skills are important for leaders in organizations (for example see Bass, 1999; Oberfield, 2014).

Furthermore, good leaders can adopt both skill sets, thus making the two types of leadership difficult to separate in practice (Bass, 1985). Findings from meta-analytic results show that transformational leadership can be fostered in the presence of transactional leadership behaviors (Judge and Piccolo, 2004). In other words, the achievement of organizational visions, in most cases, may require both the effective inspiration of employees and management of human resources over time to keep them working toward organizational goals, combined with reasonable rewards when needed. In this article, we investigate the impact of leadership trainingtransactional, transformational, and combined-on leadership. Theoretical reasons suggest that leadership training might have different effects on the skills of female and male managers.

\section{Leadership and Gender}

Because leaders come from various backgrounds and have a variety of prior experiences, they bring pre-existing advantages and disadvantages in exerting their leadership skills. The purpose of leadership training is, as such, to overcome the weaknesses and bolster the strengths (Holten, Bøllingtoft, and Wilms, 2015). The expected benefits of leadership training usually do not distinguish between men and women leaders. A framework of public leadership development by Seidle, Fernandez, and Perry (2016), for example, does not consider potential gender differences in their leadership development programs. 
However, good theoretical reasons exist to believe gender matters with regard to the effect of leadership training. According to gender role theorists, on average, women and men have contrasting individual features developed through biological sex differences and prior sexsegregated experiences (see Eagly 2013; Eagly and Wood 2016). To illustrate, in sex-segregated play groups, boys and girls might develop distinguishing play styles and different ways to influence other friends in the groups (Maccoby, 1988) or learn stereotyped gender roles from their parents (Eccles, Jacobs, and Harold, 1990). Through those socialization processes, in general, women are more likely to have communal characteristics (e.g. nurturing, unselfish, friendly, consideration), while men tend to express more agentic attributes (e.g. competence, independence, masterful, assertiveness) (Eagly and Karau, 1991; Nielsen, 2015). ${ }^{5}$ A recent article in public administration literature brings together these various arguments along with extensive empirical data and finds that women tend to be more empathic while men are more competitive and systematic and that these traits become reflected in leadership styles (Nielsen, 2015).

If women and men have genetically dissimilar attributes and have undergone different socialization processes, female and male leaders are also likely to have different leadership skills. Scholars indeed highlight that female leaders are more likely to have features of transformational leadership (Bass, Avolio, and Atwater, 1996; Eagly and Carli 2007; Eagly and Johannsen-Schmidt, 2007; Peterson and Bartels, 2017). Moreover, the meta-analytic results of 45

\footnotetext{
${ }^{5}$ Social role theorists would argue that gender distinctions might erode in organizations where group members would have shared expectations for a position. Yet, evidence from field experiments shows that gender-related traits still exist in individual members. For instance, Moskowitz, Suh, and Desaulniers (1994) found that although sexstereotype characteristics can disappear due to organizational socialization processes, communal (or agentic) attributes for women (or for men) still remain when they interact with other members in the organization (especially with the same gender, see also Nielsen, 2015).
} 
studies by Eagly, Johannesen-Schmidt, and Van Engen (2003) reveal that female leaders are perceived as more transformational leaders than men are (see also Eagly 2007).

Theories on gender roles and social expectations further articulate why women are likely to adopt transformational leadership styles. In a society and in an organization, women face much higher expectations to become successful leaders (Glass and Ingersoll 2017). They need to conform to socially desirable gender roles to be liked, and at the same time, should exert effective leadership skills to be respected. This creates a dilemma for female leaders, where they should minimize negative reactions from behaving in a masculine way (Eagly and JohannsenSchmidt 2007) all the while being highly skillful leaders. Transformational leadership is more appropriate for female leaders to satisfy social expectations and to manage this dilemma (Eagly and Carli 2007; Eagly and Johannsen-Schmidt 2007); it has collaborative, participatory, interpersonal, and democratic features, which align with women's desirable gender roles. In other words, exerting transformational styles is a less risky choice for female leaders (Eagly and Carli, 2007), as it enables them to achieve leadership goals without imposing interpersonal costs (Eagly and Johannsen-Schmidt 2007). An experimental study by Vinkenburg et al. (2011) shows that when female leaders effectively function as transformational leaders, which aligns with expected leadership styles, they are more likely to be promoted to senior management positions. This finding provides support to the theoretical arguments about the social expectations of women leaders.

Based on transformational leadership, female leaders generally pay more attention to individual needs of employees and are better at mentoring (Vinkenburg et al., 2011; Eagly, Johannesen-Schmidt, and Van Engen, 2003). In other words, women as leaders pay more attention to followers' individual opinions and seek to incorporate their needs into the 
organizational processes (for more details see Fox and Schuhmann, 1999). Female leaders are also more likely to be participative and democratic because they take individual members' perspectives seriously. This is directly associated with a greater level of members' participation in organizations. When the members are highly engaged in decision-making processes in public organizations, they have more chances to convey their perspectives in setting organizational agendas (for more details see Kim, 2002). In the process of facilitating members' participation and frequently interacting with the followers, female leaders can also have more opportunities to share and sustain organizational goals and missions, thereby enhancing employees' work attitudes, motivation, and commitment to organizational goals (Bass, Avolio, and Atwater, 1996).

While their male counterparts may prefer to have a systematic approach and tend to create a competitive environment (Nielsen, 2015), female leaders are more likely to organize a less hierarchical process and rely less on strict rules and procedures in solving organizational problems (e.g., Eagly, Johannesen-Schmidt, and Engen 2003; but see Portillo and DeHart-Davis 2009). Within this environment, women are more likely to seek to address problems using their analytical and intuitive skills (Eagly and Johnson, 1990). Since these problem-solving approaches can inspire their followers (Bass and Avolio, 1993), female leaders might exceed male leaders in transformational leadership skills (Bass, Avolio, and Atwater, 1996).

The characteristics of male leaders, in contrast, are by and large described as transactional. They tend to be more directive, autocratic, and task-oriented in exercising leadership skills, which resonates with the notion of transactional leadership (Eagly et al., 2003). Traditionally, transactional leadership was viewed more as task-oriented leadership (Bass, Avolio, and Atwater, 1996); leaders of this type are more likely to set a specific goal for their 
employees and reward or punish them based on the employees' performance in achieving the goal. Previous studies in both public and private management show that although women have the same managerial positions as men do, they use more limited managerial actions in providing incentives, rewards, and punishment to their employees, due to the hierarchical culture of organizations (Ely, Ibarra, and Kolb, 2011; South et al., 1982). Thus, transactional leadership skills are more likely to be found in male leaders.

Although the literature points to differences between male and female leaders, these differences should not be taken as deterministic. Both men and women exercise transactional and transformational leadership behaviors. The literature only finds differences in mean levels; within each gender, there is more variation in leadership behaviors within genders than there is across genders.

\section{Hypotheses}

Effective transformational leaders develop a clear vision, emphasize collaborations among employees to accomplish the vision, communicate with employees to align their goals with the shared vision, and motivate and assist employees to achieve higher goals (An, Meier, Ladenburg, and Westergård-Nielsen, 2019; Paarlberg and Lavigna, 2010). Given the collaborative, participatory, interpersonal, and democratic features (Eagly and Carli, 2007), female leaders will be more receptive to the concept of transformational leadership and more likely to internalize the information from transformational leadership training and make behavioral changes in their leadership styles accordingly. Based on the logic, we first hypothesize: 
H1: Transformational leadership training will have a larger impact for female leaders than it will for male leaders.

Transactional leadership styles emphasize setting a clear goal and valuing order and structure in organizations to reward or punish employees based on their outcomes (An, Meier, Bøllingtoft and Andersen 2019; Jensen et al. 2019). Given directive, autocratic, and task-oriented characteristics (Eagly et al., 2003), male leaders should be more receptive to the concept of transactional leadership and are likely to internalize the information from transactional leadership training and exercise the leadership skills after training. We, thus, hypothesize:

H2: Transactional leadership training will have a larger impact for male leaders than it will for female leaders.

The concepts of transformational and transactional leadership styles have been extensively studied and well known for leaders in public organizations. It is plausible, therefore, that leaders already have good knowledge of these leadership styles or exercise these leadership skills frequently. When a strong leadership style is already well established, we might expect to observe that leadership training would result in relatively less change in leadership behaviors. In other words, when a leader has higher levels of transformational leadership before our experimental intervention, the effects of transformational leadership training would result in a smaller change for that leader. Similar arguments can be made for transactional leadership and transactional leadership training. Although this is a gender-neutral hypothesis, if women rate 
higher on transformational leadership and men rate higher transactional leadership behaviors, this hypothesis might result in differences by gender.

H3: The impact of transformational leadership training will be larger for leaders with lower levels of pre-training transformational leadership behavior.

H4: The impact of transactional leadership training will be larger for leaders with lower levels of pre-training transactional leadership behavior.

\section{Research Design, Context, and Method}

\section{The Organizations and Danish Context}

Although almost all levels of governments provide various leadership training programs (Van Wart, 2003), testing the effects of leadership training in the public sector has largely focused on a few particular organizations, such as the military where female leaders are less likely to be found (for example see Dvir et al., 2002; Seidle, Fernandez, and Perry, 2016). In this study, we conducted field experiments using three different types of public organizations in Denmark: tax offices, daycare centers, and public schools. Since previous studies have mostly tested the effect of leadership training in male-dominant environments, the range of public organizations in our sample contributes to advancing generality of theories on gender and leadership;1) daycare centers are female dominant organizations at the employee and manager level (offering us a case of the least similar setting from previous studies of male-dominant organizations); 2) public schools are a mixture of female and male dominant organizations (female dominant at the employee level and male dominant at the manager level);3) tax offices serve as male dominant organizations. 
In Denmark, gender equality is relatively high even compared to other OECD countries (World Economic Forum, 2020); notably, about 40 percent of the representatives are women in the Danish parliament and the proportion of women receiving advanced degrees is greater than that of men (Statistics Denmark 2020). Such characteristics may foster gender-neutral socialization processes. In other words, with higher levels of gender equality, one can argue that expected gendered differences in transformational and/or transactional leadership styles would be marginal. Testing leadership training effects by gender in the context of Denmark, therefore, contributes to generality of leadership theories in gender, given the dominance of the US studies in this field (for a review see Eagly, Johannesen-Schmidt, and Van Engen, 2003).

\section{The Experiment}

To recruit participants for our study, we first sent invitations to all Danish leaders in the three types of organizations mentioned above-daycare centers, public primary and lower and upper secondary schools, and tax offices. The invitation letter stated that if they agree to participate in our study, they will have a $75 \%$ chance of receiving free leadership training over a year. A total of 478 leaders in the three types of organizations agreed to participate in our experiment. Over the year-long leadership experiment, 408 leaders (about 83 percent) completed leadership training sessions. The main reasons for the attrition were sickness, job changes (including promotions and transfers), and busy schedules. Figure 1 presents the number of leaders who agreed to participate in our leadership program. ${ }^{3}$

[Figure 1 about here]

\footnotetext{
${ }^{3}$ To ensure the representation of leaders from each type of organizations and avoid any potential selection bias, we stratified managers by six sub-organization groups (primary and second schools, daycare types 1,2 , and 3 , and tax offices) and then randomly assigned them to control and treatment groups.
} 
Upon the agreement of program participation, leaders were randomly assigned to three treatment groups -transformational, transactional, and combined leadership training groups - and a control group. During transactional related leadership sessions, we do not educate leaders on sanctions for ethical reasons. Although the use of rewards and/or sanctions is to enhance positive reinforcement of employee behaviors, sanctions are proven either not to be effective (Podsakoff Todor, and Skov 1982; Hansen and Pihl-Thingvad 2019) or to undermine employee behaviors such as altruism, intrinsic motivation, and work engagement (Fehr and Rockenbach 2003; Nielsen et al. 2019).

Effective leadership training should provide knowledge, feedback, and activities to reinforce leadership behaviors (Holten, Bøllingtoft, and Wilms 2015). A most recent metaanalysis study by Lacerenza and her colleagues (2017) also finds that for leadership training to be effective, leadership instructors should be able to identify of what leadership skills participants lack and then provide on-site instructions and feedback multiple times with spaced training sessions. Our leadership training is largely designed to accommodate the suggestions from previous literature. More details on leadership training can be found in Appendix E of (An et al. 2020) and the project website at https://ps.au.dk/en/research/research-projects/leapleadership-and-performance/.

To enhance the accessibility of leadership courses, four randomly assigned teachers taught small classes in seven locations close to leaders' workplaces (classes met four times over the year). During the leadership sessions, the instructors covered a 600-page curriculum on leadership, facilitated discussions among leaders, conducted course activities, and provided feedback on leadership skills. After each leadership training session, leaders were assigned coursework to be finished by the leaders before the next meeting. The training is equivalent to an 
executive master level course in Denmark and to one-month full time work for the Danish leaders.

To measure the effectiveness of leadership training, we asked both leaders and their employees to rate their leadership behaviors and their leaders' leadership behaviors before and after the leadership training interventions. Since self-raters tend to inflate ratings if survey questions are related to desirable traits (for more details see Atwater, Tammarino, and Fleenor, 1998; Meier and O'Toole, 2013), we use responses from employees' evaluation of the leaders rather than leaders' self-assessments of their own leadership skills.

In this study, we use 368 leaders and 4,352 employees in primary and secondary schools, daycare centers, and tax offices in the Danish public sector. ${ }^{6}$ In an experimental study, it is necessary to run a balance test to ensure whether randomization-in our study randomly assigning leaders to treatment groups and a control group — worked; the balance test assures the comparability of the different experimental groups. Using the pre-survey responses of managers, we check the balance of prior leadership behaviors and gender by conducting an F-test to compare the mean values among the four groups - a control and three treatment groups. The results of balance tests show no statistically significant mean differences in prior leadership behaviors and gender for managers (see Table A1). ${ }^{7}$

\section{Analytic Approach}

\footnotetext{
${ }^{6}$ We excluded 40 managers for the following reasons; a few managers did not have any directly supervised first line employees; employees for a few managers did not respond to our surveys; and some managers opted out for employee surveys for organizational concerns. Selection bias tests show these exclusions had no impact on the results of the study.

${ }^{7}$ We also run another set of balance test on organizational size (the number of employees) and managerial tenure and arrive at the same conclusion (results available upon requests).
} 
To analyze the experiment, we employ a difference-in-difference (DID) approach using ordinary least square regression models. The experimental research design and DID method allow us to investigate the clear causal effects of leadership training for female and male leaders. Since our data includes observations at multiple levels (employees and organizations), we also use robust standard errors clustered by organizations so as not to bias standard errors downward.

\section{The Dependent Variables}

We adopt transformational and transactional leadership measures from Jensen et al. (2016) since the authors redefine the concept of transformational and transactional leadership styles, so that it can be applicable not only to private organizations but also to public organizations. Using this definition of leadership, we operationalize transformational leadership as leadership behaviors developing and sustaining a shared vision with their employees and transactional leadership as behaviors relying on contingent rewards (e.g. material and nonmaterial) to achieve organizational goals.

Three dependent variables are used to measure transformational and transactional leadership styles- (1) the use of transformational leadership, (2) the use of verbal rewards, and (2) the use of material rewards. ${ }^{8}$ All the three measures use multiple items with five-point Likert scales (from $1=$ strongly disagree to $5=$ strongly agree). For the transformational leadership measure, employees answered four survey items which ask whether leaders set a clear vision for the organization, help employees accept organizational goals, clarify the ways to contribute to the achievement of organizational goals, and encourage cooperation among employees to

\footnotetext{
${ }^{8}$ The use of verbal rewards is likely to be exercised by both transactional leaders and transformational leaders.
} 
accomplish the organizational vision. The transformational leadership survey items loaded on a single factor with loadings between 0.846 and 0.898 , and a Cronbach's alpha of 0.894 .

The measure for verbal rewards is constructed using three survey items. The survey items asked employees whether leaders provide positive feedback when employees perform well, show appreciation when employees perform better than expected, and compliment their employees personally for their outstanding work. All survey items for the use of verbal rewards loaded on a single factor with correlations between 0.929 and 0.95 , and a Cronbach's alpha of 0.935 .

Three survey items are used to measure the use of material rewards. These ask employees whether their leaders clarify the types of rewards employees would receive once they meet a certain requirement, give employees rewards when they meet the requirement, and provide employees with rewards based on their performance. All the three questions again loaded in a single factor with factor loadings ranging between 0.852 and 0.921 with a Cronbach's alpha of 0.876 .

Convergent validity among the leadership measures and discriminant validity between the measures are validated via confirmatory factor analysis (for more details, see Jensen et al. 2016). Furthermore, the results above, estimated via principal components factor analysis, show that all survey items for each leadership measure loaded on a single factor and met the standards showing high factor loadings and Cronbach's alphas; our survey instruments can be regarded as reliable. To construct our dependent variables, we first add all survey items for each leadership behavior and then transform the measure to range between 0 and 100. After that, we take the first difference of leadership behaviors that are measured before and after the training interventions, which can theoretically range from -100 to 100 . If employees only responded to pre- or post- 
survey, we excluded them to avoid any bias related to individual characteristics. ${ }^{9}$ Summary statistics of key variables and reliability test results are presented in Appendix Tables 2 and 3.

\section{Findings}

Because our hypotheses suggest that there are pre-existing gender differences in the leadership styles of men and women and that these differences could affect the relative efficacy of leadership training, comparing leadership styles before training is necessary. Table 1 portrays how employees assess the leadership behaviors of their supervisors on the three measures of leadership — transformational leadership, the use of verbal rewards, and the use of material rewards. Employees rate women supervisors significantly higher on transformational leadership (72.2 versus 66.3 on the one-hundred-point scale), a finding consistent with previous literature (Eagly, Johannesen-Schmidt, and Van Engen, 2003). Substantively this difference translates into approximately one-fourth of a standard deviation for the existing sample. ${ }^{10}$ On the use of verbal rewards, behavior that is consistent with both transformational and transactional leadership nostrums, employees again rate female leaders significantly higher than male ones (65.7 compared to 60.7 on the hundred point scale, again a difference substantively of about one-fourth of a standard deviation). ${ }^{11}$ Finally, the material rewards scale is most directly tied to transactional leadership, a set of behaviors where males have generally scored higher (Eagly, Johannesen-

\footnotetext{
${ }^{9}$ We conducted a Heckman selection bias model to determine if the difference in the before and after sample could affect the results and found an insignificant level of bias.

${ }^{10}$ Women leaders self-rate themselves as 6.7 points higher on the transformational leadership scale, again a statistically significant difference. It is important to point out, however, that within gender differences are substantially larger than between gender differences. Gender never explains more than $2 \%$ of the variance in pretraining scores.

${ }^{11}$ Women also self-rate themselves 6.2 points higher on the verbal rewards scale, statistically higher than men's self-ratings.
} 
Schmidt, and Van Engen, 2003). Table 1, however, shows that while employees report female supervisors higher in the use of material rewards than male ones, the pre-training differences between female and male leaders are statistically insignificant. At least in the current sample of Danish leaders, there are no significant differences in behavior between female and male leaders before the training in the use of material rewards. ${ }^{12}$

\section{[Table 1 About Here]}

Before concluding gender differences in leadership exist based on the results from Table 1, we further examine whether the results in Table 1 are driven by the combination of manager and employee gender. Table 2 presents the average scores on the three leadership variables for various combinations of manager and employee gender from regression models. For transformational leadership, women managers receive the highest score $(\mathrm{p}<.01)$ compared to other matches though the female employee ratings on male leaders are not statistically significant. Given the fact that male employees rate female managers higher than they rate male managers and the difference is statistically significant, we find that favorable ratings toward female leaders are not necessarily from biases of gender congruence. Regarding the use of verbal rewards, female employees rate female managers higher than they rate male managers, and the difference is statistically significant. For material rewards, although both female and male employees tend to report higher scores for male managers, the differences in the rating are not statistically significant. In sum, at least in the eyes of employees, women tend to exhibit more transformational and verbal leadership behaviors than men. Given that the results in Table 2 find the same pattern as shown in Table 1, we can conclude that the findings in Table 1 are not the result of interaction patterns between the gender of leaders and the gender of followers.

\footnotetext{
${ }^{12}$ Self-ratings also show no significant differences; the ratings are within one tenth of a point of each other.
} 


\section{[Table 2 About Here]}

To assess the impact of leadership training (Tables 3 to 5), we employ changes in leadership behaviors as our dependent variables. For each of the leadership measures, we present four models. The first simply shows the impact of the leadership treatment on the leaders' behavior to provide a baseline for the analysis. The second adds gender to model 1 , the third interacts gender by the various training regimes to determine if the impact of specific types of leadership training vary by gender. The final model controls for leaders' absences from the training (a dummy variable coded 1 if the leader missed two or more training sessions), and the pre-training measure of the behavior in question (to pick up diminishing marginal returns or ceiling effects). The dependent variable is the difference in the leadership measure (as perceived by employees) after the training compared to before the training.

Table 3 presents the findings for transformational leadership. Both transformational leadership training and combined leadership training have a positive impact on the perceived behaviors of the leaders (in both cases about four points on the hundred-point scale, see model 1). ${ }^{13}$ The addition of gender to this equation in model 2 shows that gender by itself is not statistically significant. Model 3 presenting the interactions between gender and training, however, indicates that leadership training appears to be slightly more effective for women than men; but these differences are not statistically significant. Model 4 suggests some qualifications to this conclusion when pre-existing levels of leadership, and absences are included in the model. Pre-existing leadership style, as predicted, is negatively associated with changes in transformational leadership. Interpreting the results of model 4 is somewhat complicated because

\footnotetext{
${ }^{13}$ The analysis omits any experimental group not intended to affect the dependent variable, that is, Table 3 does not include pure transactional training because it is not focused on transforming the organization and Table 5 does not include pure transformational training since it does not advocate pecuniary rewards.
} 
gender by itself now is statistically significant, and the net impact of training for women needs to combine the base level of training impact (represented by men) with the interactions by gender, and the coefficient for gender. When this is done, it shows that the net change in leadership behavior for women who receive transformational leadership training is +7.1 points compared to +4 points for men $(\mathrm{f}=3.48, \mathrm{p}=.032)$; for women receiving combined training (both transformational and transactional), the gain is fully 8.4 points compared to 4.4 for men ( $\mathrm{f}=$ $7.60, p=.000)$. The $\mathrm{f}$-tests indicate that these are statistically significant differences between men and women after the experiment. Overall, these findings provide support for hypothesis 1 that transformational leadership training would be more effective for women and hypothesis 3 that preexisting levels of transformational leadership would limit the impact of leadership training.

[Table 3 About here]

Verbal rewards behavior can be part of both transformational and transactional leadership. In Table 4, model 1 shows that both combined leadership training (2.3 points) and transactional leadership (2.2 points) training have an overall positive and significant impact on the use of verbal rewards (as perceived by employees). Although transformational leadership training is associated with gains in the use of verbal rewards, the relationship fails to attain traditional levels of statistical significance. Model 2 shows that gender is not statistically significant, and none of the interaction terms in model 3 are statistically significant. This indicates no gender differences in the use of verbal rewards after leadership training. In model 4, however, the inclusion of prior levels of verbal reward leadership (absences are not significant in this case) generates a large and statistically significant coefficient for gender. Combining all the basic coefficients shows that women gain more from all three forms of leadership training: 
transformational $($ women $=+5.1$, men $=+2.3)$, combined training $($ women +6.6 , men +3.4$)$, and transactional (women +4.9 , men +3.9 ) although this appears to be the effect of gender itself rather than the training. The relationships support hypothesis 1 in regard to women and transformational leadership training and are inconsistent with hypothesis 2 for men and transactional leadership training. Women managers appear to have greater gains in the use of verbal rewards regardless of the form of leadership training. Hypotheses 3 and 4 on the diminishing returns of leadership training are supported by the negative coefficient for prior leadership levels.

\section{[Table 4 About Here]}

Greater use of material contingent rewards is a basic characteristic of transactional leadership. Model 1 in Table 5 shows that transactional leadership training, but not combined leadership training, increases employee's perceptions of contingent material rewards behavior by leaders. Although the coefficient for the more focused transactional leadership training is twice as large as that for the combined training, the confidence limits for those two coefficients overlap. Although model 2 shows that gender per se has no influence on the change in material rewards behavior, model 3 shows clear differences in training effects. Transactional leadership training appears to work for women significantly more than it works for men (about 7 points for women versus one point for men with the men's coefficient not statistically significant). Model 4, however, qualifies the relationship. When one controls for prior leadership behavior (as well as absences), both forms of leadership training are equally effective for both genders. Pure transactional leadership training has a slightly higher coefficient for women and combined training a slightly lower one for women, but neither of these coefficients reaches traditional levels of statistical significance. Comparing the net effects shows that combined training 
increases the use of material rewards by 5.7 points for men versus 3.9 for women while pure transactional training increases the use of continent material rewards by 4.1 points for men and 7.6 points for women. Neither of these gender differences is statistically significant, however, so the basic conclusion is that the effectiveness of leadership training on the use of material rewards does not differ extensively between female and male leaders. The results in Table 5 are inconsistent with hypothesis 2 .

\section{[Table 5 About Here]}

\section{Conclusions}

Although research on leadership and gender in organizations rarely engage each other in regard to empirical analysis, the present study indicates that gender adds some interesting dimensions to both the study of leadership and the study of leadership training and its effectiveness. Using a sample of public organizations in Denmark, this study found that organizational employees, on average, perceived that women managers were more likely to use transformational leadership and more likely to make use of verbal rewards (there were no differences in the use of material rewards at the start of the study). These differences were not influenced by the gender of the employees. That is, both male and female employees rated women managers higher on those leadership styles.

Despite the preexisting differences, leadership training by itself appeared equally effective in improving the skills of both male and female managers. The results, however, indicated some subtle differences. Women were in general more likely to improve on the leadership dimensions over time; and as a result, the leadership gap in favor of women actually increased over the year of the experiment. Although there was some evidence of ceiling effects 
(that is, individuals high on various dimensions did not have as much space to improve), in general pre-existing gender differences in leadership behaviors appeared to be augmented by leadership training rather than detracting from it.

The results of this study as well as the extensive non-experimental data on transformational and transactional leadership in organizations suggest that both existing literature may need to be modified. The theoretical literature on leadership in public management and human resource management is generally presented as gender neutral, yet substantial evidence now exists that women are likely to rate higher on transformational leadership than men (the evidence is more mixed for the use of material rewards, but fairly consistent on the use of verbal rewards). The existing analysis has demonstrated some differences in an experimental study. What is now needed is research on why these differences exist. One possibility is that female leaders may have better leadership skills due to double-standards that may exist for women to become a leader in organizations (Peterson and Bartels, 2017). ${ }^{14}$ To disentangle whether female leaders respond to leadership training better or they are simply better leaders, we encourage future scholars to examine the effects of leadership training on female and male leaders with similar pre-existing levels of leadership skills.

Although this is the largest experimental study on leadership training to date, it is not without limitations. First, Denmark is a small country with a strong record on gender equality. Such a situation might well provide an environment where women are encouraged to exercise leadership skills. In Denmark, given the trends of women receiving more advanced degrees

\footnotetext{
${ }^{14}$ A vast literature of sociology on women and leadership suggests that women tend to face higher standards to become a leader (see for example Ridgeway, 2001). To further illustrate, while men have a positive relation on likability and success, women tend to experience the inverse relation on the two; members of organizations tend to negatively view female employees being focused on paying their attention to success in organizations ( $\mathrm{Li}$ et al. 2012).
} 
(Statistics Denmark 2020), it is also possible that female leaders might have been more qualified for the job. Second, the study only indicated gender differences in leadership and some gender sensitivity to leadership training. We have not demonstrated that these leadership differences mattered in terms of organizational performance (although existing literature does show such correlations). Such assessments linked to this experiment will need to await the subsequent collection of performance data. Third, public organizations operate in many policy areas, and this study was limited to three government functions - education, child care, and the collection of taxes. Although these are common and significant functions for most governments, they clearly do not exhaust the possibilities. At the same time, it is fair to claim that the current study has a far more diverse set of organizations than currently exist in the public sector literature. Fourth, the leadership training in this study has a high intensity over an extended period of time using skilled trainers. The findings as a result might only apply to highly motivated leaders willing to invest a month of their time on leadership training.

The limitations suggest the need for future research. In particular, the study of leadership training in public organizations needs to follow that in the private sector and demonstrate if the gender differences found in this study are correlated with objective measures of performance (see Seidle, Fernandez, and Perry, 2016). Demonstrating that one can induce changes in leadership via training is an important first step in the process, but the objective of leadership training is to actually improve the organization. Improving the organization can take a variety of forms other than a direct effect on performance. It might be the case that leadership affects performance by improving human resources outcomes, such as morale, job satisfaction, organizational commitment, and high-performance work practices (effectively attracting, selecting, hiring, developing, and retaining high-performing individuals). Leadership can also 
improve performance by limiting the negative impact of unclear goals or by clarifying the expectations for employees. Tracing out these causal paths that could link leadership to performance would contribute greatly to the literature on public management and public human resource management knowledge base. The gendered aspects of leadership, particularly transformational leadership, suggest that integrating this literature with the growing literature on emotional labor in organizations would be promising (Guy, Newman and Mastracci, 2014). That literature shows that women are more likely to supply the emotional labor that organizations need to operate effectively. Traits more associated with women such as empathy and compassion play a role in both the transformational leadership literature and the emotional labor literature.

This article shed light on gendered aspects of leadership illustrating differences in leadership by gender - higher leadership skills prior to leadership training and greater gains post leadership training for female leaders, especially regarding transformational leadership. To enhance generality, we encourage future researchers to replicate the study in varying conditions (e.g., a country with lower gender equality, and in organizations where female and male leaders have similar leadership skills). A different contextual setting can also open more opportunities to examine whether or how intersectionality or other demographic backgrounds (e.g., tenure and education) can play out (Breslin, Pandey, \& Riccucci 2017) or how other organizational factors (e.g., decentralization and organizational culture) can moderate the tested relationship. 


\section{References}

An, S.H., Jensen, U.T., Bro, L.L., Andersen, L.B., Ladenburg, J., Meier, K.J., \& Salomonsen, H.H. Forthcoming. "Seeing Eye to Eye: Can Leadership Training Align Perceptions of Leadership?" International Public Management Journal, online first (doi: 10.1080/10967494.2020.1763533).

An, S.H., Meier, K.J., Bøllingtoft, A. and Andersen, L.B., 2019. Employee Perceived Effect of Leadership Training: Comparing Public and Private Organizations. International Public Management Journal, 22, 2-28.

An, S.H., Meier, K.J., Ladenburg, J. \& Westergård-Nielsen, N. 2019. Leadership and Job Satisfaction: Addressing Endogeneity with Panel Data from a Field Experiment. Review of Public Personnel Administration, online first.

Ashikali, T., \& Groeneveld, S. 2015. Diversity management in public organizations and its effect on employees' affective commitment: The role of transformational leadership and the inclusiveness of the organizational culture. Review of Public Personnel Administration, 35, 146-168.

Atwater, L. E., Ostroff, C., Yammarino, F. J., \& Fleenor, J. W. 1998. Self-other agreement: Does it really matter? Personnel Psychology, 51, 577-598.

Barnard, C. I. 1938. The functions of the executive. Harvard university press.

Bass, B. M. 1985. Leadership and performance beyond expectations. Free Press; Collier Macmillan.

Bass, B. M., \& Avolio, B.J. 1993. Transformational leadership and organizational culture. Public Administration Quarterly, 17, 112-121.

Bass, B. M., Avolio, B.J., Jung, D. \& Yair, B. 2003. Predicting unit performance by assessing transformational and transactional leadership. Journal of Applied Psychology, 88, 207.

Bass, B. M., Avolio, B. J., \& Atwater, L. E. 1996. The transformational and transactional leadership of men and women. Applied Psychology, 45, 5-34.

Bass, B. M., \& Stogdill, R.B. 1990. Handbook of leadership. Vol. 11 New York: Free Press.

Bass, B. M. 1999. Two decades of research and development in transformational leadership. European Journal of Work and Organizational Psychology, 8, 9-32.

Bass, B. M., \& Riggio, R. E. 2006. Transformational leadership. Psychology Press.

Breslin, R. A., Pandey, S., \& Riccucci, N. M. 2017. Intersectionality in public leadership 
research: A review and future research agenda. Review of Public Personnel Administration $37,160-182$.

Burns, J. M.G. 1978. Leadership. New York: Harper \& Row.

Caillier, J. G. 2016. Do transformational leaders affect turnover intentions and extra-role behaviors through mission valence? The American Review of Public Administration, 46, 226-242.

Dolan, J. 2000. The senior executive service: Gender, attitudes, and representative bureaucracy. Journal of Public Administration Research and Theory 10 (3):513-530.

Dvir, T., Eden, D., Avolio, B. J., \& Shamir, B. 2002. Impact of transformational leadership on follower development and performance: A field experiment. Academy of Management Journal, 45, 735-744.

Eagly, A. H. 2007. Female leadership advantage and disadvantage: Resolving the contradictions. Psychology of Women Quarterly, 31, 1-12.

Eagly, A. H. 2013. Sex differences in social behavior: A social-role interpretation. Psychology Press.

Eagly, A. H., \& Johnson, B. T. 1990. Gender and leadership style: A meta-analysis. Psychological Bulletin, 108, 233-256.

Eagly, A. H., Johannesen-Schmidt, M. C., \& Van Engen, M. L. 2003. Transformational, transactional, and laissez-faire leadership styles: a meta-analysis comparing women and men. Psychological Bulletin, 129, 569-591.

Eagly, A. H., \& Karau, S. K. 1991. Gender and the emergence of leaders: A meta-analysis. Journal of Personality and Social Psychology, 60, 685-710.

Eagly, A.H. and Wood, W., 2016. Social role theory of sex differences. The Wiley Blackwell encyclopedia of gender and sexuality studies, pp.1-3.

Eccles, J. S., Jacobs, J. E., \& Harold, R. D. 1990. Gender role stereotypes, expectancy effects, and parents' socialization of gender differences. Journal of Social Issues, 46,183-201.

Ely, R. J., Ibarra, H., \& Kolb, D. M. 2011. Taking gender into account: Theory and design for women's leadership development programs. Academy of Management Learning \& Education, 10, 474-493.

Fehr, E. and Rockenbach, B., 2003. Detrimental effects of sanctions on human altruism. Nature, 422, 137-140.

Ferguson, K. E. 1985. The feminist case against bureaucracy. Philadelphia, PA: Temple University Press. 
Fox, R. L., \& Schuhmann, R. A. 1999. Gender and local government: A comparison of women and men city managers. Public Administration Review, 59, 231-242.

Garcia-Retamero, R. \& Lopez-Zafra, E. 2006. Prejudice against women in male-congenial environments: Perceptions of gender role congruity in leadership. Sex Roles, 55, 51-61.

Guy, M. E., Newman, M. A., \& Mastracci, S. H. 2014. Emotional labor: Putting the service in public service. New York: Routledge.

Hamidullah, M.F., N.M. Riccucci, and S.K. Pandey. 2015. "Women in City Hall: Gender Dimensions of Managerial Values." American Review of Public Administration. 45(3): 247-262.

Hansen, J.A. and Pihl-Thingvad, S. 2019. Managing employee innovative behaviour through transformational and transactional leadership styles. Public Management Review, 21, 918944.

Holten, A.-L., Bøllingtoft, A., \& Wilms, I. 2015. Leadership in a changing world: developing managers through a teaching and learning programme. Management Decision, 53, 11071124.

Jacobson, W.S., C.K. Palus, \& C.J. Bowling. 2010. A woman's touch? Gendered management and performance in state administration. Journal of Public Administration Research and Theory 20 (2):477-504.

Jensen, U. T., Andersen, L. B., Bro, L. L., Bøllingtoft, A., Eriksen, T. L. M., Holten, A. L., \& Westergård-Nielsen, N. (2016). Conceptualizing and measuring transformational and transactional leadership. Administration \& Society.

Judge, T. A., \& Piccolo, R. F. 2004. Transformational and transactional leadership: a metaanalytic test of their relative validity. Journal of Applied Psychology, 89, 755-768.

Kim, S. 2002. Participative management and job satisfaction: Lessons for management leadership. Public Administration Review, 62, 231-241.

Lacerenza, C.N., Reyes, D.L., Marlow, S.L., Joseph, D.L. and Salas, E. 2017. Leadership training design, delivery, and implementation: A meta-analysis. Journal of Applied Psychology, 102, 1686-1718.

Li, W.-D., Arvey, R. D. Zhang, Z. \& Song, Z. 2012. Do leadership role occupancy and transformational leadership share the same genetic and environmental influences?. The Leadership Quarterly 23, 233-243.

Maccoby, E. E. 1988. Gender as a social category. Developmental Psychology, 24, 755-765.

Meier, K. J., \& O'Toole Jr, L. J. 2013. I think (I am doing well), therefore I am: Assessing the validity of administrators' self-assessments of performance. International Public Management Journal, 16, 1-27 
Meier, K. J., L.J. O'Toole, and H.T. Goerdel. 2006. Management activity and program performance: Gender as management capital. Public Administration Review 66 (1):24-36.

Moskowitz, D. S., Suh, E., \& Desaulniers, J. 1994. Situational influences on gender differences in agency and communion. Journal of Personality and Social Psychology, 66, 753-761.

Nielsen, V. L. 2015. Personal attributes and institutions: Gender and the behavior of public employees. Why gender matters to not only 'Gendered Policy Areas'. Journal of Public Administration Research and Theory, 25, 1005-1029.

Nielsen, P.A., Boye, S., Holten, A.L., Jacobsen, C.B. and Andersen, L.B. 2019. Are transformational and transactional types of leadership compatible? A two-wave study of employee motivation. Public Administration, 97, 413-428.

Oberfield, Z. W. 2014. Public management in time: a longitudinal examination of the full range of leadership theory. Journal of Public Administration Research and Theory, 24, 407-429.

Peterson, S. J. \& Bartels, A. L. 2017. Using neuroscience methods to explore gender differences in leadership. In Mandsen, S. R. (Eds.), Handbook of research on gender and leadership (pp. 238-253). Northampton, MA: Edward Elgar Publishing, Inc.

Podsakoff, P.M., Todor, W.M. and Skov, R. 1982. Effects of leader contingent and noncontingent reward and punishment behaviors on subordinate performance and satisfaction. Academy of Management Journal, 25, 810-821.

Portillo, S., \& DeHart-Davis, L. 2009. Gender and organizational rule abidance. Public Administration Review, 69, 339-347.

Ridgeway, C.L. 2001. Gender, status, and leadership. Journal of Social issues, 57, 637-655.

Seidle, B., Fernandez, S., \& Perry, J. L. 2016. Do leadership training and development make a difference in the public sector? A panel study. Public Administration Review, 76, 604-613.

Simon, H. A. 1976. Administrative behavior. 3 ed. New York: The Free Press.

South, S. J., Bonjean, C. M., Corder, J., \& Markham, W. T. 1982. Sex and power in the federal bureaucracy a comparative analysis of male and female supervisors. Work and Occupations, $9,233-254$.

Statistics Denmark. 2020. "Gender Equality in Denmark." Accessed at https://www.dst.dk/en/Statistik/emner/levevilkaar/ligestilling/ligestillingswebsite\#2 (January 27, 2020)

Stivers, C. 2002. Gender images in public administration: Legitimacy and the administrative state. Sage Publications. 
Terry, L. D. 2003. Leadership of Public Bureaucracies: The Administrator as Conservator. ME Sharpe.

Vigoda-Gadot, E., \& Beeri, I. 2012. Change-oriented organizational citizenship behavior in public administration: The power of leadership and the cost of organizational politics. Journal of Public Administration Research and Theory, 22, 573-596.

Van Wart, M. 2003. Public-Sector leadership theory: An assessment. Public Administration Review, 63, 214-228.

Van Wart, Montgomery. 2013. Administrative leadership theory: A reassessment after 10 years. Public Administration 91 (3): 521-543.

Vinkenburg, C. J., Van Engen, M. L., Eagly, A. H., \& Johannesen-Schmidt, M. C. 2011. An exploration of stereotypical beliefs about leadership styles: Is transformational leadership a route to women's promotion? The Leadership Quarterly, 22, 10-21.

World Economic Forum. 2020. "Global Gender Gap Report 2020.” Accessed at http://www3.weforum.org/docs/WEF_GGGR_2020.pdf (January 27, 2020)

Wright, B. E., Moynihan, D. P., \& Pandey, S. K. 2012. Pulling the levers: Transformational leadership, public service motivation, and mission valence. Public Administration Review, 72, 206-215. 


\section{Tables and Figures}

\section{Tables}

Table 1: Do female and male leaders have different levels of leadership styles?

\begin{tabular}{|c|c|c|c|}
\hline $\begin{array}{l}\text { D.V.s: Employee Perceived Leadership } \\
\text { Behaviors }\end{array}$ & $\begin{array}{l}\text { Transformational } \\
\text { Leadership }_{t 1} \\
\text { Model } 1\end{array}$ & $\begin{array}{l}\text { Verbal } \\
\text { Rewards }_{t 1} \\
\text { Model } 2\end{array}$ & $\begin{array}{l}\text { Material } \\
\text { Rewards }_{t 1} \\
\text { Model } 3\end{array}$ \\
\hline Gender of Managers $($ Female $=1)$ & $\begin{array}{l}5.974 * * \\
(1.681)\end{array}$ & $\begin{array}{l}4.962 * * \\
(1.675)\end{array}$ & $\begin{array}{c}1.891 \\
(1.528)\end{array}$ \\
\hline Constant (Male mean) & $\begin{array}{c}66.257 * * \\
(1.118)\end{array}$ & $\begin{array}{c}60.735 * * \\
(1.149)\end{array}$ & $\begin{array}{c}36.222 * * \\
(1.123)\end{array}$ \\
\hline R-Squared overall & 0.0189 & 0.0090 & 0.0017 \\
\hline N (managers) & 275 & 368 & 286 \\
\hline N (employees) & 3229 & 4291 & 3183 \\
\hline
\end{tabular}

Notes: $+\mathrm{p}<0.10, * \mathrm{p}<0.05,{ }^{* *} \mathrm{p}<0.01$; robust clustered standard errors at the organizational level.

Interpretation: the constant is the mean level for male leaders. The gender coefficient is how much more (or less) the female's leaders score on the scale. 
Table 2: The effects of gender congruence between leaders and employees on employee perceived leadership behaviors

\begin{tabular}{|c|c|c|c|c|}
\hline \multicolumn{2}{|c|}{ Gender } & \multicolumn{3}{|c|}{ Leadership Styles } \\
\hline Manager & Employee & $\begin{array}{l}\text { Transformational } \\
\text { Leadership }_{t 1}\end{array}$ & $\begin{array}{l}\text { Verbal } \\
\text { Rewards }_{t 1}\end{array}$ & $\begin{array}{l}\text { Material } \\
\text { Rewards }_{t 1}\end{array}$ \\
\hline Women & Women & $73.39^{* *}$ & $65.18 * *$ & 35.29 \\
\hline Men & Women & 67.78 & $64.21+$ & $40.11 * *$ \\
\hline Women & Men & $67.01 * *$ & $60.07 * *$ & $33.68 * *$ \\
\hline Men & Men & $63.99 *$ & 60.41 & 34.46 \\
\hline \multicolumn{2}{|c|}{ F-Statistics } & 10.84 & 2.32 & 3.54 \\
\hline \multicolumn{2}{|c|}{ Prob. $>$ F } & 0.00 & 0.08 & 0.00 \\
\hline \multirow{2}{*}{\multicolumn{2}{|c|}{$\mathrm{N}$ (managers) }} & 265 & 356 & 275 \\
\hline & & 2378 & 3163 & 2377 \\
\hline
\end{tabular}

Note: $+\mathrm{p}<0.10,{ }^{*} \mathrm{p}<0.05,{ }^{* *} \mathrm{p}<0.01$; robust clustered standard errors at the organizational level.

Interpretation: All scores are the means for the manager-employee combinations, that is women employees rate women leaders as 73.39 on transformational leadership and they rate male managers 67.78 on transformational leadership. 
Table 3: The effects of leadership training on employee perceived leadership behaviors (the use of transformational leadership) by gender

\begin{tabular}{|c|c|c|c|c|}
\hline DV: $\Delta$ Transformational Leadership & Model 1 & Model 2 & Model 3 & Model 4 \\
\hline Transformational Leadership Training & $\begin{array}{c}4.195 * * \\
(1.225)\end{array}$ & $\begin{array}{c}4.105 * * \\
(1.223)\end{array}$ & $\begin{array}{l}3.993 * \\
(1.903)\end{array}$ & $\begin{array}{l}3.975 * \\
(1.913)\end{array}$ \\
\hline Combined Leadership Training & $\begin{array}{c}3.537 * * \\
(1.089)\end{array}$ & $\begin{array}{c}3.485 * * \\
(1.064)\end{array}$ & $\begin{array}{c}2.190 \\
(1.500)\end{array}$ & $\begin{array}{c}4.396 * * \\
(1.588)\end{array}$ \\
\hline Gender $($ Female $=1)$ & & $\begin{array}{c}1.156 \\
(0.934)\end{array}$ & $\begin{array}{c}0.105 \\
(1.549)\end{array}$ & $\begin{array}{c}4.531 * * \\
(1.734)\end{array}$ \\
\hline Gender $\times$ Transformational & & & $\begin{array}{c}0.365 \\
(2.430)\end{array}$ & $\begin{array}{l}-1.429 \\
(2.569)\end{array}$ \\
\hline Gender $\times$ Combined & & & $\begin{array}{c}2.701 \\
(2.078)\end{array}$ & $\begin{array}{l}-0.501 \\
(2.107)\end{array}$ \\
\hline High Absences ( $1=$ two or more absences $)$ & & & & $\begin{array}{l}-1.892 \\
(1.382)\end{array}$ \\
\hline Transformational $_{t 1}$ & & & & $\begin{array}{c}-0.423 * * \\
(0.023)\end{array}$ \\
\hline Constant & $\begin{array}{c}-1.846^{*} \\
(0.799) \\
\end{array}$ & $\begin{array}{c}-2.368 * \\
(0.983) \\
\end{array}$ & $\begin{array}{c}-1.894 \\
(1.243) \\
\end{array}$ & $\begin{array}{c}25.632 * * \\
(1.946) \\
\end{array}$ \\
\hline R-Squared overall & 0.0089 & 0.0097 & 0.0107 & 0.2251 \\
\hline $\mathrm{N}$ (managers) & 275 & 275 & 275 & 275 \\
\hline N (employees) & 3229 & 3229 & 3229 & 3229 \\
\hline
\end{tabular}

Notes: $+\mathrm{p}<0.10, * \mathrm{p}<0.05, * * \mathrm{p}<0.01$; robust clustered standard errors at the organizational level. 
Table 4: The effects of leadership training on employee perceived leadership behaviors (the use of verbal rewards) by gender

\begin{tabular}{|c|c|c|c|c|}
\hline DV: $\Delta$ Verbal Rewards & Model 1 & Model 2 & Model 3 & Model 4 \\
\hline Transformational Leadership Training & $\begin{array}{c}1.983 \\
(1.313)\end{array}$ & $\begin{array}{c}1.901 \\
(1.301)\end{array}$ & $\begin{array}{c}1.016 \\
(1.895)\end{array}$ & $\begin{array}{c}2.336 \\
(1.957)\end{array}$ \\
\hline Combined Leadership Training & $\begin{array}{l}2.342+ \\
(1.322)\end{array}$ & $\begin{array}{l}2.298+ \\
(1.303)\end{array}$ & $\begin{array}{c}1.158 \\
(1.835)\end{array}$ & $\begin{array}{c}3.405 \\
(2.073)\end{array}$ \\
\hline Transactional Leadership Training & $\begin{array}{l}2.199+ \\
(1.201)\end{array}$ & $\begin{array}{l}2.071+ \\
(1.206)\end{array}$ & $\begin{array}{c}3.129 \\
(1.925)\end{array}$ & $\begin{array}{l}3.855+ \\
(2.119)\end{array}$ \\
\hline Gender $($ Female $=1)$ & & $\begin{array}{c}0.933 \\
(0.930)\end{array}$ & $\begin{array}{c}0.306 \\
(1.653)\end{array}$ & $\begin{array}{l}4.329^{*} \\
(1.883)\end{array}$ \\
\hline Gender $\times$ Transformational & & & $\begin{array}{c}1.749 \\
(2.580)\end{array}$ & $\begin{array}{l}-1.562 \\
(2.678)\end{array}$ \\
\hline Gender $\times$ Combined & & & $\begin{array}{c}2.358 \\
(2.553)\end{array}$ & $\begin{array}{l}-1.142 \\
(2.662)\end{array}$ \\
\hline Gender $\times$ Transactional & & & $\begin{array}{l}-1.656 \\
(2.424)\end{array}$ & $\begin{array}{l}-3.235 \\
(2.632)\end{array}$ \\
\hline High Absences ( $1=$ two or more absences) & & & & $\begin{array}{l}-1.829 \\
(1.541)\end{array}$ \\
\hline Verbal Rewards $_{t 1}$ & & & & $\begin{array}{c}-0.375^{* *} \\
(0.016)\end{array}$ \\
\hline Constant & $\begin{array}{c}-2.371^{* *} \\
(0.848) \\
\end{array}$ & $\begin{array}{c}-2.789^{* *} \\
(0.991) \\
\end{array}$ & $\begin{array}{l}-2.508+ \\
(1.282)\end{array}$ & $\begin{array}{c}19.481 * * \\
(1.759) \\
\end{array}$ \\
\hline R-Squared overall & 0.0018 & 0.0022 & 0.0034 & 0.1862 \\
\hline $\mathrm{N}$ (managers) & 368 & 368 & 368 & 368 \\
\hline N (employees) & 4291 & 4291 & 4291 & 4291 \\
\hline
\end{tabular}

Notes: $+\mathrm{p}<0.10,{ }^{*} \mathrm{p}<0.05,{ }^{* *} \mathrm{p}<0.01$; robust clustered standard errors at the organizational level. 
Table 5: The effects of leadership training on employee perceived leadership behaviors (the use of material rewards) by gender

\begin{tabular}{lcccc}
\hline DV: $\Delta$ Material Rewards & Model 1 & Model 2 & Model 3 & Model 4 \\
\hline Combined Leadership Training & 1.905 & 1.888 & $3.291+$ & $5.723^{* *}$ \\
& $(1.288)$ & $(1.292)$ & $(1.762)$ & $(1.922)$ \\
Transactional Leadership Training & $4.459^{* *}$ & $4.411^{* *}$ & 0.993 & $4.139^{*}$ \\
& $(1.323)$ & $(1.323)$ & $(1.882)$ & $(1.993)$ \\
Gender (Female=1) & & 0.349 & -0.686 & 2.265 \\
& & $(1.113)$ & $(1.598)$ & $(1.829)$ \\
Gender $\times$ Combined Leadership Training & & & -2.710 & -4.047 \\
& & & $(2.553)$ & $(2.503)$ \\
Gender $\times$ Transactional Leadership Training & & & $6.082^{*}$ & 1.156 \\
& & & $(2.552)$ & $(2.669)$ \\
High Absences $(1=$ two or more absences) & & & & $-6.479^{* *}$ \\
& & & & $(1.351)$ \\
Material Rewards & & & & $-0.492^{* *}$ \\
& & & & $(0.017)$ \\
Constant & $-2.030^{*}$ & $-2.187^{*}$ & -1.723 & $15.336^{* *}$ \\
& $(0.799)$ & $(0.954)$ & $(1.103)$ & $(1.392)$ \\
\hline R-Squared overall & 0.0060 & 0.0060 & 0.0120 & 0.2471 \\
N (managers) & 286 & 286 & 286 & 286 \\
N (employees) & 3183 & 3183 & 3183 & 3183 \\
\hline
\end{tabular}

Notes: $+\mathrm{p}<0.10, * \mathrm{p}<0.05, * * \mathrm{p}<0.01$; robust clustered standard errors at the organizational level. 


\section{Appendix}

Table A1: Balance tests for managers

\begin{tabular}{lcccc}
\hline Treatment and control groups & Transformational leadership $_{t 1}$ & Verbal rewards $_{\mathrm{t} 1}$ & Material rewards $_{t 1}$ & Gender \\
\hline Transformational leadership training & 83.36 & 84.15 & 47.74 & 0.49 \\
Combined leadership training & 85.69 & 83.05 & 44.2 & 0.52 \\
Transactional leadership training & 82.42 & 83.34 & 46.25 & 0.62 \\
Control & 86 & 83.26 & 43.85 & 0.52 \\
\hline Prob. > F & 0.15 & 0.96 & 0.62 & 0.3 \\
N (managers) & 364 & 364 & 364 & 368 \\
\hline
\end{tabular}


Table A2: Summary Statistics

\begin{tabular}{lrrrrr}
\hline Variable & Obs & \multicolumn{1}{c}{ Mean } & \multicolumn{1}{l}{ S.D. } & \multicolumn{1}{l}{ Min } & Max \\
\hline$\Delta$ Transformational Leadership & 3,229 & 0.71 & 19.55 & -100 & 100 \\
$\Delta$ Verbal Rewards & 4,291 & -0.74 & 22.75 & -100 & 100 \\
$\Delta$ Material Rewards & 3,183 & 0.08 & 23.51 & -100 & 100 \\
Gender of Managers (Female=1) & 4,352 & 0.52 & 0.50 & 0 & 1 \\
Transformational Leadership Training & 4,352 & 0.24 & 0.43 & 0 & 1 \\
Combined Leadership Training & 4,352 & 0.26 & 0.44 & 0 & 1 \\
Transactional Leadership Training & 4,352 & 0.25 & 0.43 & 0 & 1 \\
High Absences (two or more absences=1) & 4,352 & 0.16 & 0.37 & 0 & 1 \\
\hline
\end{tabular}

Table A3: Factor loadings for employee perceived leadership behavior indicators

Transformational Leadership Indicators Loading

[leader's name] concretizes a clear vision for the [organization's] future 0.862

[leader's name] seeks to make employees accept common goals for the [organization] 0.846

[leader's name] strives to get the [organization's] employees to work together in the

direction of the vision

0.898

[leader's name] strives to clarify for the employees how they can contribute to

achieving the [organization's] goals

0.883

Cronbach's alpha $=0.894$

Verbal Rewards Indicators

Loading

[leader's name] gives individual employees positive feedback when they perform well 0.944

[leader's name] actively shows his/her appreciation of employees who do their jobs

better than expected

0.925

[leader's name] personally compliments employees when they do outstanding work

0.95

Cronbach's alpha $=0.935$

Material Rewards Indicators

Loading

[leader's name] rewards the employees' performance when they live up to his/her

requirements

0.921

[leader's name] rewards the employees' dependent on how well they perform their jobs

0.913

[leader's name] points out what employees will receive if they do what is required

0.852

Cronbach's alpha $=0.876$ 


\section{Figure}

Figure 1: Numbers of managers who agreed to participate and completed leadership training by types of organizations.

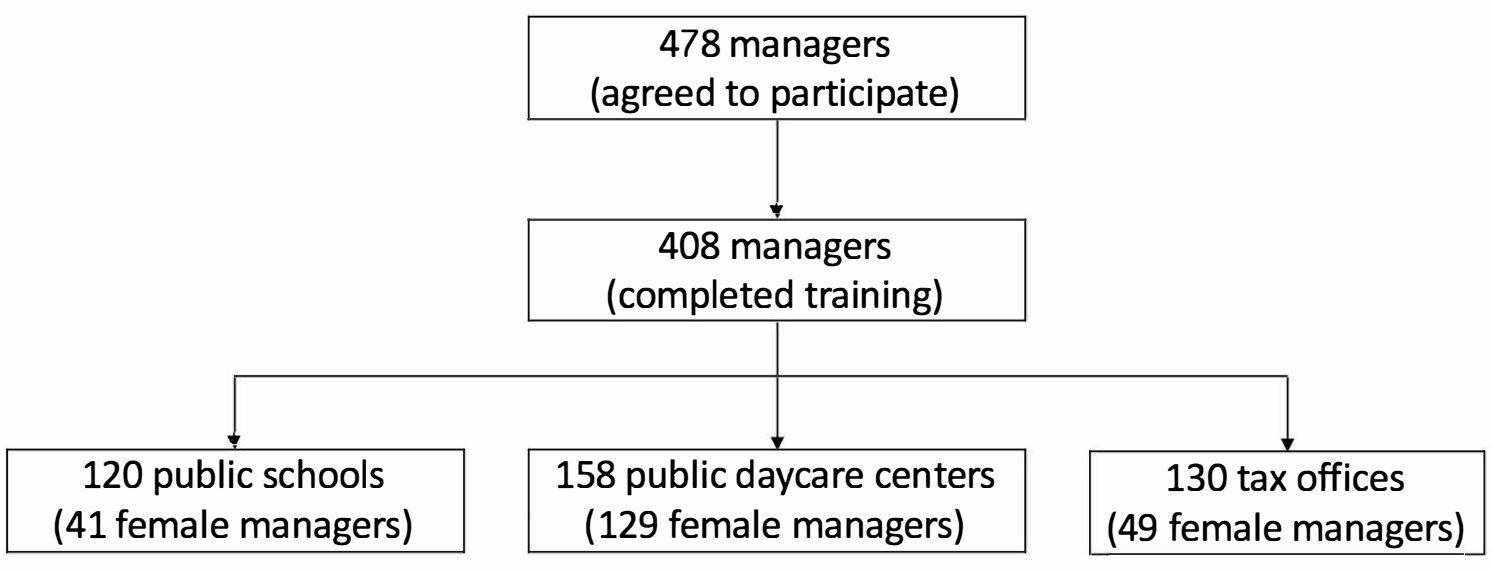

